TITLE:

\title{
Effect of acetic acid addition on chemical conversion of woods as treated by semi-flow hot- compressed water
}

\section{$\operatorname{AUTHOR}(\mathrm{S}):$}

Phaiboonsilpa, Natthanon; Saka, Shiro

\section{CITATION:}

Phaiboonsilpa, Natthanon ...[et al]. Effect of acetic acid addition on chemical conversion of woods as treated by semi-flow hot-compressed water. Holzforschung 2011, 65(5): 667672

\section{ISSUE DATE:}

2011-02

URL:

http://hdl.handle.net/2433/158042

RIGHT:

2011 Copyright (c) by Walter de Gruyter de Gruyter • Berlin • Boston 


\section{Effect of acetic acid addition on chemical conversion of woods as treated by semi-flow hot-compressed water}

\author{
Natthanon Phaiboonsilpa and Shiro Saka* \\ Graduate School of Energy Science, Kyoto University, \\ Yoshida-honmachi, Sakyo-ku, Kyoto 606-8501, Japan \\ *Corresponding author. \\ Department of Socio-Environmental Energy Science, Graduate \\ School of Energy Science, Kyoto University Yoshida-honmachi, \\ Sakyo-ku, Kyoto 606-8501, Japan \\ Phone/Fax: +81-75-753-4738 \\ E-mail: saka@energy.kyoto-u.ac.jp
}

\begin{abstract}
Effect of acetic acid $(\mathrm{AcOH})$ addition on chemical conversion of Japanese beech (Fagus crenata), as a hardwood, and Japanese cedar (Cryptomeria japonica), as a softwood, was investigated in the course of treatment in a semi-flow reactor with hot-compressed water (H-CW). One-step treatment of Japanese beech was preliminarily performed to examine the effect of $\mathrm{AcOH}$ concentrations on the decomposition behavior at $150-290^{\circ} \mathrm{C} / 10 \mathrm{MPa} / 30 \mathrm{~min}$. Based on the obtained results, two-step semi-flow $\mathrm{H}-\mathrm{CW}$ treatment with $1 \mathrm{wt} \%$ $\mathrm{AcOH}$ at $210^{\circ} \mathrm{C} / 10 \mathrm{MPa} / 15 \mathrm{~min}$ (1st stage) and $260^{\circ} \mathrm{C} /$ $10 \mathrm{MPa} / 15 \mathrm{~min}$ (2nd stage) was thus selected as the most appropriate treatment and a comparative study of the two woods was accordingly conducted. The differences in decomposition behavior observed between the two woods clearly proved that the addition of $\mathrm{AcOH}$ played an important role in enhancing the hydrolysis and decomposition of cell wall components in Japanese cedar due to the lesser amount of acetyl residue in softwood hemicelluloses and its lignin structure.
\end{abstract}

Keywords: acetic acid; chemical conversion; hardwood; hotcompressed water; hydrolysis; Japanese beech; Japanese cedar; softwood.

\section{Introduction}

Acetic acid $(\mathrm{AcOH})$ process has long been known as an effective method for delignification in the pulp and paper industry (Nimz and Casten 1986; Sano et al. 1989, 1990; Pan et al. 1998). This particular process is generally conducted under the conditions: $105^{\circ} \mathrm{C}$; atmospheric pressure or above; $0.5-4 \mathrm{~h}$; $\mathrm{AcOH}$ aqueous solution $90 \%-95 \%$; mineral acid catalyst (e.g. $\mathrm{HCl}$ or $\mathrm{H}_{2} \mathrm{HO}_{4}$ ) $0.1 \%-4 \%$ (Sano et al. 1990; Parajó et al. 1993; Pan and Sano 2005). Cellulose, hemicelluloses, and lignin in lignocellulosic materials can be dissolved and degraded under these conditions. The obtained $\mathrm{AcOH}$ pulp is composed mainly of cellulose, which possesses a comparable physical strength to the conventional pulps for papermaking. Acetic acid lignin can serve as feedstocks for many value-added lignin products due to its lower molecular weight and higher reactivity. In addition, the sugars from hemicelluloses are readily convertible to chemicals and fuels (Pan and Sano 2005).

Recently, we have conducted a two-step hydrolysis of Japanese beech (Fagus crenata) and Japanese cedar (Cryptomeria japonica), in the course of which the woods are treated in a semi-flow reactor with hot-compressed water (H-CW) at $230^{\circ} \mathrm{C} / 10 \mathrm{MPa} / 15 \mathrm{~min}$ (1st stage) and $270-280^{\circ} \mathrm{C} /$ $10 \mathrm{MPa} / 15-30 \mathrm{~min}$ (2nd stage) (Lu et al. 2009; Phaiboonsilpa et al. 2009, 2010a,b; Saka et al. 2009). In such studies, a substantial production of decomposed compounds was realized in the 2nd stage due to its relatively high treatment temperature. These decomposed compounds can end up with loss of saccharides, and inhibitory effect can occur on the subsequent fermentation step resulting in a lower yield of ethanol.

This earlier finding prompted the necessity for our further study to lessen the decomposed compounds by means of reducing the treatment temperature. Addition of $\mathrm{AcOH}$ into the reaction mixture was an alternative to achieve this goal; in addition, the presence of $\mathrm{AcOH}$ presents no drawback to the subsequent process steps in our newly-developed ecoethanol production process via $\mathrm{AcOH}$ fermentation and hydrogenolysis (Saka et al. 2009).

In this paper, therefore, the effect of $\mathrm{AcOH}$ addition on chemical conversion of Japanese beech (as a hardwood) and Japanese cedar (as a softwood) in H-CW treatment will be investigated. The most appropriate treatment conditions for the hydrolysis of hemicelluloses and cellulose are sought, whereby the production level of decomposed compounds should be minimized.

\section{Experimental}

\section{Materials}

Extractives-free wood samples of Japanese beech (Fagus crenata) and Japanese cedar (Cryptomeria japonica) were prepared according to the method described by Lu et al. (2009) and Phaiboonsilpa et al. (2009, 2010a). Chemical composition of the wood samples are described in the quoted papers. All chemicals were of reagent grade and used without purification. 


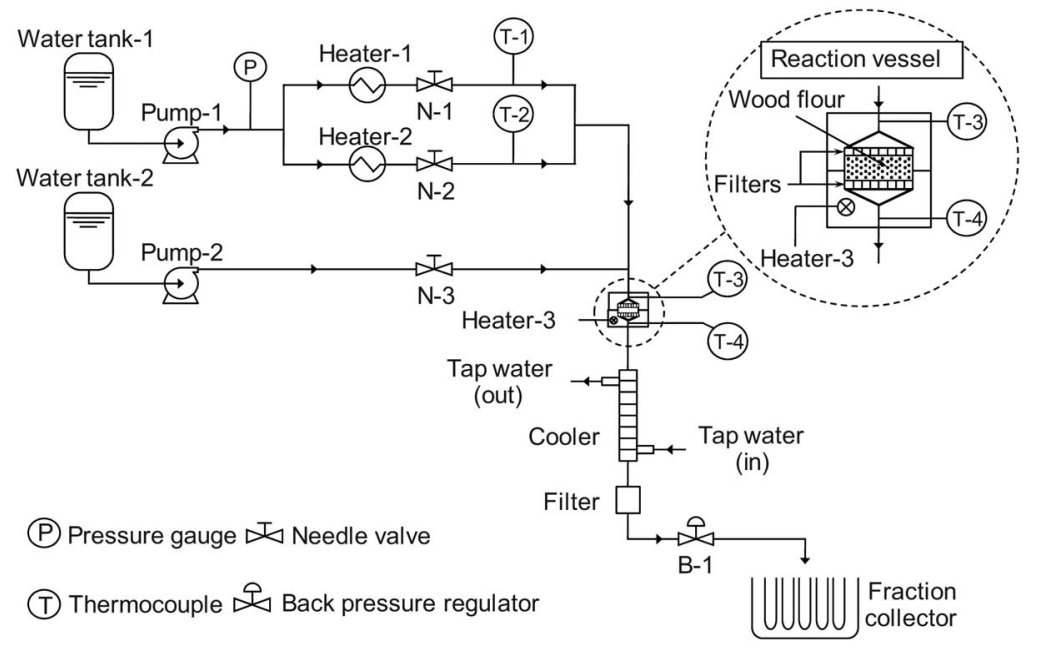

Figure 1 Schematic diagram of the semi-flow H-CW treatment system used in our studies.

\section{$\mathrm{H}-\mathrm{CW}$ treatment and fractionation of the products}

Figure 1 illustrates a schematic diagram of the semi-flow $\mathrm{H}-\mathrm{CW}$ treatment system used in our studies. Its detailed operational procedures were described by $\mathrm{Lu}$ et al. (2009). Instead of distilled water, $0.1,1$, and $3 \mathrm{wt} \% \mathrm{AcOH}$ aqueous solutions were prepared and stored in water tank-1. Approximately $0.5-1 \mathrm{~g}$ of extractivesfree wood flour was placed in the reaction vessel and treated by

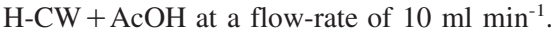

Solubles in $\mathrm{H}-\mathrm{CW}$ were collected and left at the ambient temperature and pressure for $12 \mathrm{~h}$. After being filtrated over a $0.45-\mu \mathrm{m}$ membrane, the water-soluble portion was then subjected to subsequent analyses. The solid residue remaining in the reaction vessel after the treatment was oven-dried and analyzed.

As a preliminary study, Japanese beech was treated by one-step semi-flow $\mathrm{H}-\mathrm{CW}+\mathrm{AcOH}(0.1 \%, 1 \%$, and $3 \%)$ at temperatures between $150-290^{\circ} \mathrm{C}$; pressure $10 \mathrm{MPa}$; time $30 \mathrm{~min}$. The best conditions found were employed in the subsequent two-step treatment.

\section{Analyzes of products}

Acetic acid was removed from the water-soluble portion by freezedrying. Distilled water was then added to adjust its volume back to the initial stage. The AcOH-free samples were then analyzed by HPAEC, HPLC, and capillary electrophoresis (CE) as described by Lu et al. (2009) and Phaiboonsilpa et al. (2010a). All the product percentages were presented on oven-dried weight basis of the extractives-free wood flour.

The Klason lignin determination was performed according to Dence (1992) and Minami and Saka (2003). The crystallographic structure of cellulose was characterized by X-ray diffractometry.

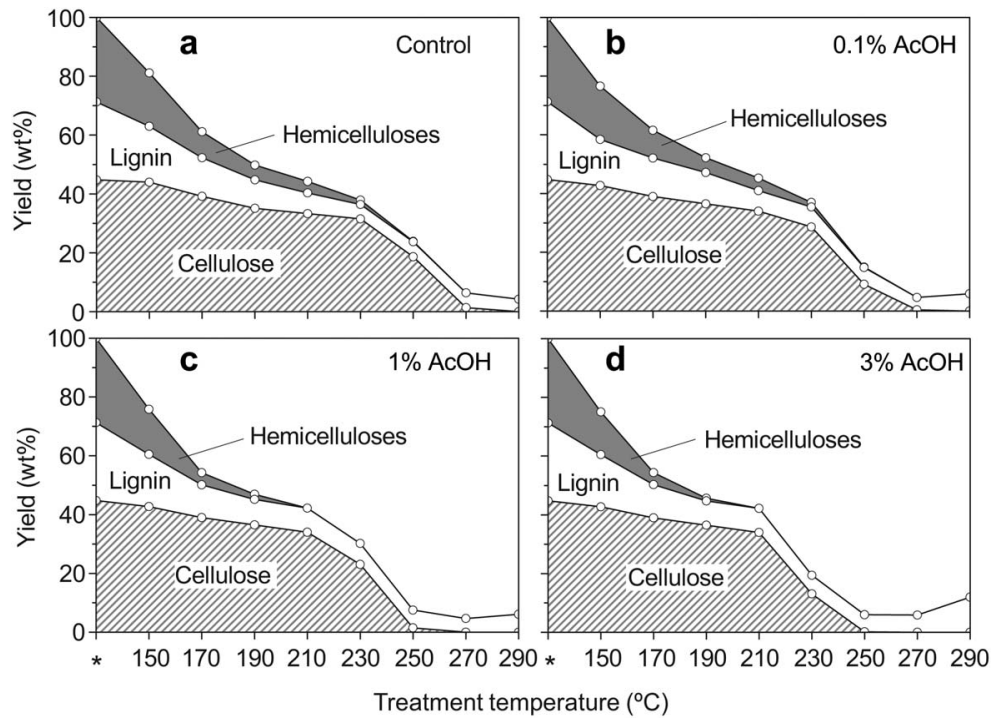

Figure 2 Change in chemical composition of Japanese beech residues as treated in a semi-flow reactor with hot-compressed water at $150-290^{\circ} \mathrm{C} / 10 \mathrm{MPa} / 30 \mathrm{~min}$. (a) Without $\mathrm{AcOH}$ (control), (b) $0.1 \% \mathrm{AcOH}$, (c) $1 \% \mathrm{AcOH}$, and (d) $3 \% \mathrm{AcOH}$. Asterisks (*) denote the composition of untreated wood. 
Apparent crystallinity was estimated as the method described by Segal et al. (1959).

\section{Results and discussion}

\section{Effect of AcOH addition}

Figure 2 shows changes in chemical composition of Japanese beech residues as treated by one-step semi-flow $\mathrm{H}-\mathrm{CW}$ with $0.1 \%, 1 \%$, and $3 \% \mathrm{AcOH}$ at $150-290^{\circ} \mathrm{C} / 10 \mathrm{MPa} / 30 \mathrm{~min}$. For comparison, the treatment without $\mathrm{AcOH}$ addition is presented in Figure 2a. The results clearly demonstrate that hemicelluloses and cellulose are liquefied completely in the presence of $\mathrm{AcOH}$ at lower temperatures. Higher acid concentrations display a greater decomposition degree. On the other hand, as a result of acid addition, no such a significant difference in lignin decomposition was observed at 150$250^{\circ} \mathrm{C}$. At a higher temperature, however, the residual lignin was increased. The most pronounced effects can be seen in the treatment with $3 \% \mathrm{AcOH}$ at $290^{\circ} \mathrm{C}$ (Figure 2d). This observation might be attributed to the condensation reaction of lignin.

As recognized in the literature (Davis et al. 1986; Parajó et al. 1995; Vázquez et al. 1997), the decomposition behavior of lignin can be satisfactorily explained by a model corresponding to dissolution followed by condensation and reprecipitation of the lignin onto the lignocellulosic matrix. It was also reported by the same authors that the selectivity of lignin condensation became dominant when the treatment severity was high enough. Therefore, the lignin condensation observed in this present study can be confirmed.

From Figure 3a, it is clear that changes in Japanese beech residues do not show a great difference for all the treatments at temperatures between 150 and $210^{\circ} \mathrm{C}$, where hemicelluloses were mainly hydrolyzed whereas lignin and cellulose were decomposed in part (see Figure 2). Nonetheless, those changes in the treatment with $\mathrm{AcOH}$ varied more apparently at $210-270^{\circ} \mathrm{C}$. In this temperature range, hemicelluloses were already removed from the system and only cellulose and lignin were subjected to the treatment. As seen from Figure 2, lignin is likely to be decomposed at the same degree over this temperature range. Therefore, the differences observed at $210-270^{\circ} \mathrm{C}$ are mainly attributable to the cellulose decomposition.

These results can be explained by the different chemical composition of hemicelluloses, which contain not only various polysaccharides but also acetyl and uronic acid groups. These acids can be liberated in the course of hydrothermal treatment and serve as a catalyst in hydrolysis, a process, which is known as autohydrolysis (Lora and Wayman 1978; Laser et al. 2002). For this reason, the additional AcOH does not show a significant effect on improving the hydrolysis of hemicelluloses in the case of the hardwood Japanese beech.

Figure $3 \mathrm{~b}$, moreover, demonstrates that the crystalline structure of cellulose could be readily destroyed at lower temperatures in presence of $\mathrm{AcOH}$, and higher acid concentrations increase the effect. At $150^{\circ} \mathrm{C}$, however, the crystallinity was elevated. This can be explained by an effective removal of amorphous moieties of the cell wall-i.e., lignin and hemicelluloses - with the assistance of the additional $\mathrm{AcOH}$ at a relatively low temperature.

\section{Hydrolyzed products from hemicelluloses and cellulose}

Figure $3 \mathrm{c}$ shows the production of xylo- and cello-saccharides from Japanese beech after a one-step $\mathrm{H}-\mathrm{CW}$ treatment in a semi-flow reactor in presence of $\mathrm{AcOH}$ at $150-290^{\circ} \mathrm{C}$. Evidently, the acid addition does not help significantly to increase the yields of xylo-saccharides. However, an excessive decomposition of the hydrolyzed products of hemicelluloses can be observed, as seen on the yields at $210^{\circ} \mathrm{C}$. As for cello-saccharides, although higher yields could be attained at even lower temperatures in presence of $\mathrm{AcOH}$.
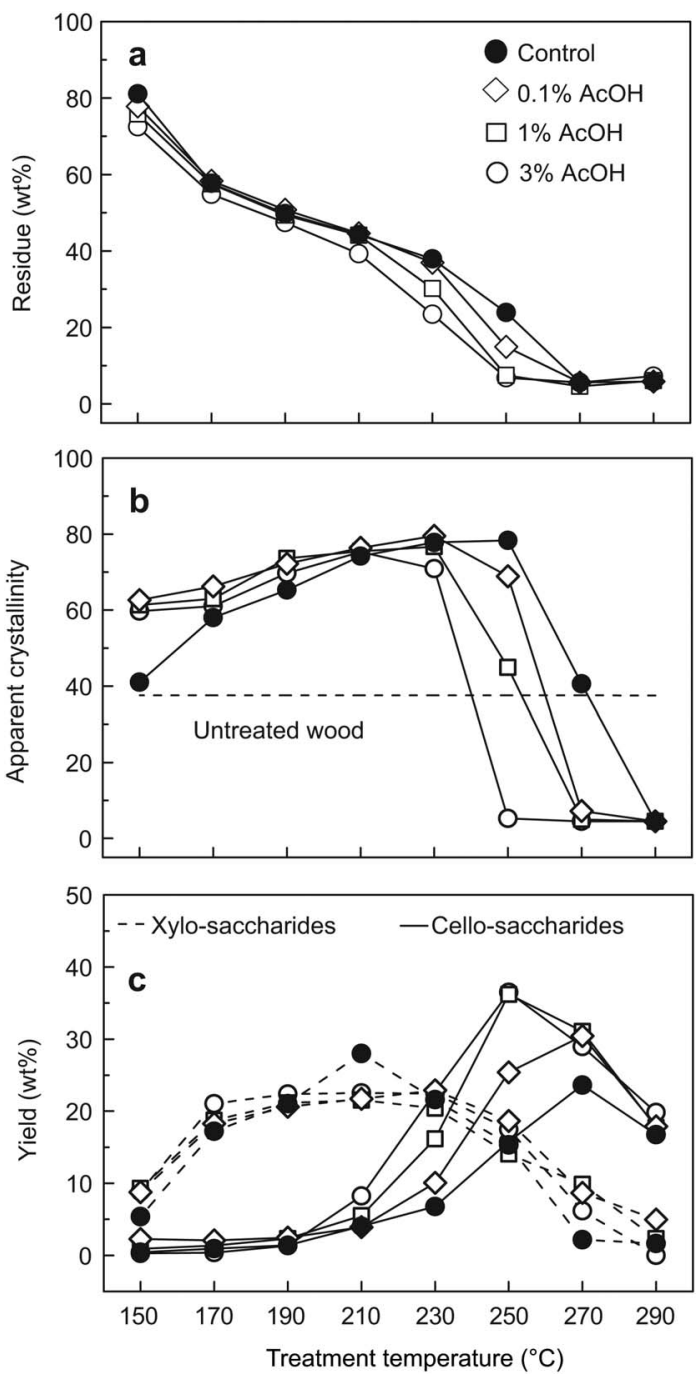

Figure 3 Change in yield (a) and apparent crystallinity (b) of wood residues, and production of saccharides (c) from Japanese beech after treatment in a semi-flow reactor with hot-compressed water with $0 \%, 0.1 \%, 1 \%$, and $3 \% \mathrm{AcOH}$ at $150-290^{\circ} \mathrm{C} / 10 \mathrm{MPa} /$ $30 \mathrm{~min}$. 
The difference with respect to the hydrolysis behaviors between hemicelluloses and cellulose is also obvious here.

Based on the previous results, the parameters $210^{\circ} \mathrm{C} / 10$ $\mathrm{MPa} / 15$ min were chosen for the 1 st stage. As seen from Figure $3 \mathrm{c}$, the substantial increases in cello-saccharide yields could be obtained at $250{ }^{\circ} \mathrm{C}$ in presence of $1 \%$ and $3 \%$ $\mathrm{AcOH}$. To minimize the corrosion effect, $1 \%$ acid concentration was preferred. However, Figure $3 \mathrm{~b}$ indicates that cellulose crystallinity seems to be drastically destroyed at temperatures higher than $250^{\circ} \mathrm{C}$ with $1 \% \mathrm{AcOH}$. Therefore, the parameters $260^{\circ} \mathrm{C} / 10 \mathrm{MPa} / 15$ min with $1 \% \mathrm{AcOH}$ were thus set as tolerable conditions for the 2 nd stage.

\section{Two-step treatment with/without acetic acid}

Various products from Japanese beech and Japanese cedar are summarized in Table 1, which were obtained by a twostep $\mathrm{H}-\mathrm{CW}$ treatment in a semi-flow reactor with $1 \% \mathrm{AcOH}$, with 1 st step $210^{\circ} \mathrm{C} / 10 \mathrm{MPa} / 15 \mathrm{~min}$ and 2 nd step $260^{\circ} \mathrm{C} /$ $10 \mathrm{MPa} / 15 \mathrm{~min}$.

In the case of Japanese beech, hydrolyzed products from hemicelluloses are as follows: xylo-saccharides—such as xylose and xylo-oligosaccharides-mannose, galactose, arabinose, rhamnose, glucuronic acid and methanol. Those of Japanese cedar are glucomanno-saccharides-such as mannose, glucose and oligomeric glucomannan-galactose, xylo-saccharides-such as xylose and xylo-oligosaccharides-arabinose, glucuronic acid and methanol. Hydrolyzed products from cellulose include cello-saccharides-such as glucose and cello-oligosaccharides - and fructose, as an isomerized product from glucose. Total amounts of ligninderived products are estimated from the lignin content in the original wood meal and that in the solid residue after the $\mathrm{H}-\mathrm{CW}$ treatment.
Dehydrated compounds include levoglucosan, 5-hydroxymethylfurfural (5-HMF) and furfural; fragmented compounds refer to erythrose, methylglyoxal and glycolaldehyde; and organic acids are lactic, glycolic and formic acids. Unknown product can be calculated as follows: unknown = $100 \%$-total recovery product yields $(\%)$-residue $(\%)$.

From Table 1, it is visible that the two-step treatment with $1 \% \mathrm{AcOH}$ could be performed at temperatures $10-20^{\circ} \mathrm{C}$ lower than those of the treatment without acid addition, while similar product yields were obtained. Namely, $230^{\circ} \mathrm{C}(1 \mathrm{st}$ stage) and $270^{\circ} \mathrm{C}$ (2nd stage) could be reduced to $210^{\circ} \mathrm{C}$ and $260^{\circ} \mathrm{C}$, respectively. In total, $93.7 \%$ and $92.2 \%$ of Japanese beech were solubilized in $\mathrm{H}-\mathrm{CW}$ with and without $\mathrm{AcOH}$. As for Japanese cedar, the soluble portion increased from $82.3 \%$ to $83.7 \%$ as a result of the acid addition. The rest of around $6 \%-8 \%$ of Japanese beech and $12 \%-14 \%$ of Japanese cedar were left as solid residues composed mainly of lignin, conversion products of polysaccharides, and cellulose incompletely hydrolyzed. The yield of residues was higher in the case of Japanese cedar, due to its higher lignin content and the higher portion of less soluble condensed-type linkages of guiacyl units in its (softwood) lignin.

The catalytic effect of $\mathrm{AcOH}$ for delignification of both woods is obvious. However, the acid addition is less effective to increase the hydrolyzed products from hemicelluloses and cellulose for Japanese beech. In case of Japanese cedar, on the other hand, the acid addition has a significant effect on the hydrolysis of hemicelluloses and cellulose.

Table 2 is a compilation of molar ratios between sugar and acid residues in the major hardwood and softwood hemicelluloses according to Timell (1967). As demonstrated here, softwood hemicelluloses possess less acetyl group than that of hardwoods. This is the reason why additional AcOH plays

Table 1 Comparison of various products from Japanese beech and Japanese cedar as treated by two-step semi-flow hot-compressed water (1st $230^{\circ} \mathrm{C} / 10 \mathrm{MPa} / 15 \mathrm{~min}$ and $\left.2 \mathrm{nd} 270^{\circ} \mathrm{C} / 10 \mathrm{MPa} / 15 \mathrm{~min}\right)$ and two-step semi-flow hot-compressed water with $1 \mathrm{wt} \% \mathrm{AcOH}\left(1 \mathrm{st} 210^{\circ} \mathrm{C} /\right.$ $10 \mathrm{MPa} / 15 \mathrm{~min}$ and $\left.2 \mathrm{nd} 260^{\circ} \mathrm{C} / 10 \mathrm{MPa} / 15 \mathrm{~min}\right)^{\mathrm{a}-\mathrm{c}}$.

\begin{tabular}{|c|c|c|c|c|c|c|c|c|c|}
\hline \multirow[b]{3}{*}{$\begin{array}{c}\text { Two-step } \\
\text { hot-compressed } \\
\text { water treatment }\end{array}$} & \multicolumn{9}{|c|}{ Yield (wt $\%$ on extractives-free wood basis) } \\
\hline & \multicolumn{7}{|c|}{ Hot-compressed water-soluble portion } & \multicolumn{2}{|c|}{ Residue } \\
\hline & $\begin{array}{l}\text { Hydrolyzed } \\
\text { prod. from } \\
\text { hemicelluloses }\end{array}$ & $\begin{array}{l}\text { Hydrolyzed } \\
\text { products from } \\
\text { cellulose }\end{array}$ & $\begin{array}{l}\text { Lignin- } \\
\text { derived } \\
\text { products }\end{array}$ & $\begin{array}{l}\text { Dehydrated } \\
\text { compounds }\end{array}$ & $\begin{array}{l}\text { Fragmented } \\
\text { compounds }\end{array}$ & $\begin{array}{c}\text { Organic } \\
\text { acids }\end{array}$ & Unknown & Lignin & Saccharides $^{\mathrm{a}}$ \\
\hline \multicolumn{10}{|l|}{ Japanese beech } \\
\hline Without AcOH & $\begin{array}{c}28.7 \\
(100.0)^{\mathrm{b}}\end{array}$ & $\begin{array}{c}28.1 \\
(62.7)\end{array}$ & $\begin{array}{c}19.9 \\
(76.8)\end{array}$ & 2.0 & 0.7 & 0.8 & 12.0 & $\begin{array}{c}6.0 \\
(23.2)\end{array}$ & $\begin{array}{l}1.8 \\
(4.0)\end{array}$ \\
\hline With $1 \% \mathrm{AcOH}$ & $\begin{array}{c}28.1 \\
(97.9)\end{array}$ & $\begin{array}{c}29.7 \\
(66.3)\end{array}$ & $\begin{array}{c}21.0 \\
(81.1)\end{array}$ & 2.8 & 1.0 & 1.1 & 10.0 & $\begin{array}{c}4.9 \\
(18.9)\end{array}$ & $\begin{array}{c}1.4 \\
(3.1)\end{array}$ \\
\hline \multicolumn{10}{|l|}{ Japanese cedar } \\
\hline Without $\mathrm{AcOH}$ & $\begin{array}{c}18.9 \\
(100.0)\end{array}$ & $\begin{array}{c}31.2 \\
(64.6)\end{array}$ & $\begin{array}{c}18.8 \\
(58.2)\end{array}$ & 1.9 & 2.4 & 0.4 & 8.7 & $\begin{array}{c}13.5 \\
(41.8)\end{array}$ & $\begin{array}{c}4.2 \\
(8.7)\end{array}$ \\
\hline With $1 \% \mathrm{AcOH}$ & $\begin{array}{c}22.2 \\
(116.2)\end{array}$ & $\begin{array}{c}44.1 \\
(91.3)\end{array}$ & $\begin{array}{c}19.6 \\
(60.7)\end{array}$ & 2.0 & 2.5 & 0.4 & $\mathrm{ND}^{\mathrm{c}}$ & $\begin{array}{c}12.7 \\
(39.3)\end{array}$ & $\begin{array}{c}3.6 \\
(7.5)\end{array}$ \\
\hline
\end{tabular}

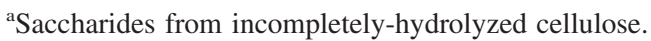

bItalic values in parentheses indicate relative \% of products from hemicelluloses, cellulose, and lignin compared to their contents in original extractives-free wood flour.

${ }^{\mathrm{c}} \mathrm{ND}$, not determined. 
Table 2 Comparison of molar ratio between sugar and acid residues in the major hardwood and softwood hemicelluloses (Timell 1967).

\begin{tabular}{lcllc}
\hline $\begin{array}{c}\text { Hardwood hemicelluloses } \\
(O \text {-acetyl- } O \text {-methylglucuronoxylan })\end{array}$ & & \multicolumn{2}{c}{$\begin{array}{c}\text { Softwood hemicelluloses } \\
(O \text {-acetyl-galactoglucomannan })\end{array}$} \\
\cline { 5 - 6 } \multicolumn{1}{c}{ Residue } & Molar ratio & & Residue & Molar ratio \\
\hline Acetic acid & 10 & & Acetic acid & 0.24 \\
Glucuronic acid & 1 & & Galactose & $0.1-1$ \\
Xylose & 7 & & Glucose & 1 \\
& & Mannose & 3 \\
\hline
\end{tabular}

an important role in enhancing the hydrolysis of cell wall components in Japanese cedar.

Based on the configuration of semi-flow system, liberated $\mathrm{AcOH}$ and other organic acids from the hydrolysis in the 1st stage were flushed from the reaction vessel. As a consequence, the acids cannot serve as catalysts in the 2nd stage, where only cellulose and remaining lignin were left. The effect of $\mathrm{AcOH}$ addition is nearly identical at this stage for both woods. However, additional $\mathrm{AcOH}$ might help improve cellulose hydrolysis by reacting with softwood lignin, but a clear explanation for this observation cannot be given at this moment.

The hydrolyzed saccharides from both woods were recovered to a higher extent in monomeric form in the presence of $\mathrm{AcOH}$ (Table 3). Glucose and its oligosaccharides are derived mainly from cellulose during hydrolysis in the 2nd stage, while the other saccharides are from hemicelluloses in the 1st stage. Fructose is a result of isomerization of glucose. It is obvious that the additional $\mathrm{AcOH}$ can promote the hydrolysis of soluble oligosaccharides obtained in both stages.

More extensive decomposition reactions occur in the presence of $\mathrm{AcOH}$, as indicated by the higher yields of dehydrated and fragmented compounds, as well as organic acids (Table 1). The two-step process with $\mathrm{H}-\mathrm{CW}$ in the presence of $\mathrm{AcOH}$ needs more optimization.

\section{Conclusions}

Hemicelluloses and cellulose are readily liquefied at lower temperatures in the presence of $\mathrm{AcOH}$. The acid, however, elevates the tendency of condensation reaction of lignin at higher temperatures. The hydrolysis of wood with $\mathrm{H}-\mathrm{CW}$ in a two-step process can be performed at $10-20^{\circ} \mathrm{C}$ lower temperatures in the presence of $1 \% \mathrm{AcOH}$. The product yields are satisfactory in comparison with experiments without $\mathrm{AcOH}$. The decomposition behavior of the hardwood and

Table 3 Comparison of various saccharides from Japanese beech $(F . c$. $)$ and Japanese cedar $(C . j$. recovered in monomeric and oligomeric forms as treated by two-step semi-flow hot-compressed water with and without acetic acid (\% data based on wt of extractives-free wood flour) ${ }^{\mathrm{a}}$.

\begin{tabular}{|c|c|c|c|c|c|c|c|c|}
\hline \multirow[b]{3}{*}{ Saccharide } & \multicolumn{4}{|c|}{ 2-Step treatment without $\mathrm{AcOH}$} & \multicolumn{4}{|c|}{ 2-Step treatment with $1 \% \mathrm{AcOH}$} \\
\hline & \multicolumn{2}{|c|}{ Monomer } & \multicolumn{2}{|c|}{ Oligomer } & \multicolumn{2}{|c|}{ Monomer } & \multicolumn{2}{|c|}{ Oligomer } \\
\hline & F. $c$. & C. $j$. & F. $c$. & C. $j$. & F. $c$. & C. $j$. & F. $c$. & C. $j$. \\
\hline \multirow[t]{2}{*}{ Glucose } & 4.4 & 5.5 & 24.1 & 27.9 & 11.2 & 10.2 & 16.7 & 34.9 \\
\hline & $(15.4)^{\mathrm{a}}$ & $(16.5)$ & $(84.6)$ & $(83.5)$ & $(40.1)$ & $(22.6)$ & $(59.9)$ & $(77.4)$ \\
\hline \multirow[t]{2}{*}{ Mannose } & 0.1 & 0.5 & 1.8 & 7.7 & 0.3 & 1.0 & 0.9 & 7.7 \\
\hline & $(5.3)$ & $(6.1)$ & $(94.7)$ & $(93.9)$ & $(25.0)$ & $(11.5)$ & $(75.0)$ & $(88.5)$ \\
\hline \multirow[t]{2}{*}{ Galactose } & 0.1 & 0.4 & 0.6 & 1.0 & 0.2 & 0.5 & 0.6 & 1.1 \\
\hline & $(14.3)$ & $(28.6)$ & $(85.7)$ & $(71.4)$ & $(25.0)$ & $(31.3)$ & $(75.0)$ & $(68.7)$ \\
\hline \multirow[t]{2}{*}{ Rhamnose } & 0.1 & - & 0.4 & - & 0.2 & - & 0.4 & - \\
\hline & $(20.0)$ & - & $(80.0)$ & - & $(33.3)$ & - & $(66.7)$ & - \\
\hline \multirow[t]{2}{*}{ Xylose } & 1.0 & 1.2 & 20.6 & 4.5 & 2.6 & 2.7 & 18.0 & 5.6 \\
\hline & $(4.6)$ & $(21.1)$ & $(95.4)$ & $(78.9)$ & $(12.6)$ & $(32.5)$ & $(87.4)$ & $(67.5)$ \\
\hline \multirow[t]{2}{*}{ Arabinose } & 0.2 & 0.4 & 0.3 & 0.4 & 0.3 & 0.5 & 0.3 & 0.2 \\
\hline & $(40.0)$ & $(50.0)$ & $(60.0)$ & $(50.0)$ & $(50.0)$ & (71.4) & $(50.0)$ & $(28.6)$ \\
\hline Fructose & 0.5 & 0.5 & - & - & 2.4 & 1.9 & - & - \\
\hline
\end{tabular}

a Italic values in parentheses show relative $\%$ based on its total mono- and oligo-saccharide contents obtained in each treatment. 
softwood investigated here was different. The efficient utilization of woods for biochemicals and biofuels by means of $\mathrm{H}-\mathrm{CW}$ treatment needs a lot of optimization in larger experimental units, and feasibility studies are needed to check its economic viability.

\section{Acknowledgements}

This work has been done as in part of the NEDO project (FYs 2007-2010), "Eco-ethanol production from lignocellulosics with hot-compressed water treatment followed by acetic acid fermentation and hydrogenolysis". Partial financial support from the Global Center of Excellence (GCOE) Program, Kyoto University, is highly acknowledged.

\section{References}

Davis, J.L., Young, R.A., Deodhar, S.S. (1986) Organic acid pulping of wood. III. Acetic acid pulping of spruce. Mokuzai Gakkaishi 32:905-914.

Dence, C.W. (1992) The determination of lignin. In: Methods in Lignin Chemistry. Ed. Lin, S.Y., Dence, C.W. Springer, Berlin, pp. 33-63.

Laser, M., Schulman, D., Allen, S.G., Lichwa, J., Antal, M.J., Lynd, L.R. (2002) Comparison of liquid hot water and steam pretreatments of sugar cane bagasse for bioconversion to ethanol. Bioresource Technol. 81:33-44.

Lora, J.H., Wayman, M. (1978) Delignification of hardwoods by autohydrolysis and extraction. Tappi J. 61:47-50.

Lu, X., Yamauchi, K., Phaiboonsilpa, N., Saka, S. (2009) Two-step hydrolysis of Japanese beech as treated by semi-flow hot-compressed water. J. Wood Sci. 55:367-375.

Minami, E., Saka, S. (2003) Comparison of the decomposition behaviors of hardwoods and softwoods in supercritical methanol. J. Wood Sci. 49:73-78.

Nimz, H.H., Casten, R. (1986) Chemical processing of lignocellulosics. Holz Roh Werkst. 44:207-212.

Pan, X.J., Sano, Y. (2005) Fractionation of wheat straw by atmospheric acetic acid process. Bioresource Technol. 96:1256-1263.

Pan, X.J., Sano, Y., Nakashima, H., Uraki, Y. (1998) Atmospheric acetic acid pulping of rice straw. I: Pulping conditions and properties of pulp (in Japanese). Jpn. Tappi J. 52:408-415.
Parajó, J.C., Alonso, J.L., Vázquez, D. (1993) On the behaviour of lignin and hemicelluloses during the acetosolv processing of wood. Bioresource Technol. 46:233-240.

Parajó, J.C., Alonso, J.L., Santos, V. (1995) Kinetics of catalyzed organosolv processing of pine wood. Ind. Eng. Chem. Res. 34:4333-4342.

Phaiboonsilpa, N., Lu, X., Yamauchi, K., Saka, S. (2009) Chemical conversion of lignocellulosics as treated by two-step semi-flow hot-compressed water. In: Proceedings of the World Renewable Energy Congress 2009-Asia, Bangkok, Thailand, pp. 235-240.

Phaiboonsilpa, N., Yamauchi, K., Lu, X., Saka, S. (2010a) Two-step hydrolysis of Japanese cedar as treated by semi-flow hot-compressed water. J. Wood Sci. 56:331-338.

Phaiboonsilpa, N., Lu, X., Yamauchi, K., Saka, S. (2010b) Chemical conversion of lignocellulosics as treated by two-step hot-compressed water. In: Zero-Carbon Energy Kyoto 2009. Ed. Yao, T. Green Energy and Technology, Springer, pp. 166-170.

Saka, S., Phaiboonsilpa, N., Nakamura, Y., Masuda, S., Lu, X., Yamauchi, K., Miyafuji, H., Kawamoto, H. (2009) Eco-ethanol production from lignocellulosics with hot-compressed water treatment followed by acetic acid fermentation and hydrogenolysis. In: Proceedings of the17th European Biomass Conference and Exhibition, Hamburg, Germany, pp. 1952-1957.

Sano, Y., Maeda, H., Sakashita, Y. (1989) Pulping of wood at atmospheric pressure. I. Pulping of hardwoods with aqueous acetic acid containing a small amount of organic sulfonic acid. Mokuzai Gakkaishi 35:991-995.

Sano, Y., Nakamura, M., Shimamoto, S. (1990) Pulping of wood at atmospheric pressure. II: Pulping of hardwoods with aqueous acetic acid containing a small amount of sulfuric acid, Mokuzai Gakkaishi 36:207-211.

Segal, L., Creely, J.J., Martin, A.E., Conrad, C.M. (1959) An empirical method for determining the degree of crystallinity of native cellulose using the X-ray diffractometer. Text. Res. J. 29:786794.

Timell, T.E. (1967) Recent progress in chemistry of wood hemicelluloses. Wood Sci. Technol. 1:45-70.

Vázquez, G., Antorrena, G., González, J., Freire, S., López, S. (1997) Acetosolv pulping of pine wood. Kinetic modelling of lignin solubilization and condensation. Bioresource Technol. 59:121-127.

Received September 2, 2010. Accepted January 11, 2011. Previously published online February 25, 2011. 